\title{
In-vitro Cytotoxic Activity of Oleanolic \& Cincholic acids isolated from Lotus glaber-mill herb (Family, Fabaceae)
}

\author{
Aya Mohamed ${ }^{1}$, Mona A. Mohamed ${ }^{2}$, Ahmed B.M. Mehany ${ }^{3}$, Hala Sh. Mohammed ${ }^{1}$ \\ ${ }^{1}$ Department of Pharmacognosy, Faculty of Pharmacy (Girls), Al Azhar University, Cairo 11754, Egypt. \\ ${ }^{2}$ Department of Medicinal Chemistry, Teodor Bilharz Research Institute, Giza 12411, Egypt. \\ ${ }^{3}$ Department of Zoology, Faculty of Science (Boys), Al Azhar University, Cairo 11754, Egypt. \\ * Correspondence: ayaa.sharaf@gmail.com
}

Article history: Received 27-12-2020 Revised 07-01-2021 Accepted 10-01-2021

\begin{abstract}
In the current study, antiproliferative effects of 3 - hydroxyl- Olean - 12 - en - 28 - oic acid (Oleanolic acid ; OA) \& 3-ß-hydroxyolean - 12-en-27, 28 dioic acid (Cincholic acid; CA); triterpene sapogenins isolated from the ethyl-acetate fraction of Lotus glaber-mill herb were evaluated against three human cancer cell lines, the liver cancer cell line( HepG-2), the colon cancer cell line (HCT-116), \& the breast cancer cell line (MCF-7). The structures of isolated phytoconstituents were identified by careful analysis of 1D NMR spectra and negative ESI-MS data. Oleanolic acid \& Cincholic acid displayed cytotoxic activities against the tested cell lines. Oleanolic acid has lower IC $_{50}$ than Cincholic acid for both MCF-7 \& HCT-116 at $27.99 \& 18.66 \mu \mathrm{g} / \mathrm{ml}$ respectively. While Cincholic acid has a lower $\mathrm{IC}_{50}$ in HEPG-2 than Oleanolic acid at $22.81 \mu \mathrm{g} / \mathrm{ml}$. Further investigations have shown that Oleanolic acid \& Cincholic acid- induce apoptosis and cause cell cycle arrest at the G2/M phase.
\end{abstract}

Keywords: Cincholic; Oleanolic; sapogenin; Antiproliferative; HEPG-2.

\section{INTRODUCTION}

The naturally occurring modified triterpenes in plants have a large diversity of chemical structures and biological functions. Especially, oleanane-, lupane-, and ursane-type triterpenes have cytotoxic effects on various cancer cell lines and are considered anti-cancer agents ${ }^{1,2}$. Their cytotoxicity is affected by the type of basic backbone and the number and position of derivatives, such as alkyl, hydroxyl, carboxyl, and amino acids ${ }^{3,4}$. $\beta$ - amyrin, the major group of the triterpenoid sapogenins is usually simple alcohol and acids. Cincholic acid (CA) and oleanolic acid (OA), are examples of $\beta$-amyrin group triterpenoid aglycones ${ }^{5}$. Oleanolic acid (OA) is a sapogenin that is common in the form of a free acid or saponin glycosides found in medicinal herbs and is distributed widely in plants all over the world ${ }^{6}$. In recent years, it has been found that oleanolic acid has marked anti-tumor effects, the literature survey reveals that oleanolic acid could be a highly potent compound that shows a cytotoxic activities ${ }^{7}$.

The cytotoxicity test is one of the most important $\mathrm{m}$ easures of the in-vitro biological assessment framework for the observation of cell growth, repro duction, and morphological effects by chemical and the advancement of cell biology; experimental meth ods for the assessment of cytotoxicity are also being continuously established and improved ${ }^{8}$.

CA structurally related to $\mathbf{O A}$, the $\mathrm{Me}-27$ at $\mathbf{O A}$ is a carboxylic group in $\mathbf{C A}$, both compounds isolated from the ethyl-acetate fraction of Lotus glaber-mill herb and the aim of the current study is to evaluate the anti-proliferated effect of CA in comparison with OA on different human cancer cell lines.

\section{MATERIAL AND METHODS}

\subsection{Plant material}

The herb Lotus glaber-mill (2.5 kg) was collected from the entrance of Cairo-Suez road, Egypt, in April 2017. The plants were authenticated by Prof. Dr. Abd El Halim Abd El Motjale, Chief Researches and Head of Flora \& Phytotaxonomy Researches Department, Agriculture Museum. A 
voucher specimen (No. 3346) of the plant was deposited in the herbarium of Flora \& Phytotaxonomy Researches Department, Agriculture Museum, Dokki, Giza, Egypt.

\subsection{Extraction and Isolation}

Air-dried herb $(2.5 \mathrm{Kg})$ was extracted three times with $70 \%$ aqueous methanol (4L) at room temperature $\left(25 \pm 2{ }^{\circ} \mathrm{C}\right)$, the extract was concentrated via a rotatory evaporator (Buchi Co., Switzerland) till dryness to afford $250 \mathrm{~g}$ total extract.

It was then defatted with $2 \mathrm{~L}$ petroleum ether $\left(60-80^{\circ} \mathrm{C}\right)$ to afford petroleum ether extract $(30 \mathrm{~g})$. The defatted extract $(200 \mathrm{~g})$ was subjected to fractionation with $2 \mathrm{~L}$ ethyl-acetate and $2 \mathrm{~L}$ n-butanol to afford ethyl-acetate fraction $(40 \mathrm{~g})$ and butanol fraction $(70 \mathrm{~g})$. the ethyl acetate fraction $(40 \mathrm{~g})$ was subjected to silica gel (Sigma Aldrich, USA) column chromatography $(\mathrm{CC})(5 \mathrm{~cm}$ X $120 \mathrm{~cm}$, flow rate $1.5 \mathrm{ml} / \mathrm{min}$ ) eluted by methylene chloride/methanol mixtures of increasing polarities by the addition of methanol in 10\% increments till 100\% methanol. By using thin layer chromatogram (TLC) (aluminum-coated silica gel $60 \mathrm{~F}_{254}$, Germany) using methylene chloride /methanol/water $(80: 20: 2, \mathrm{v} / \mathrm{v} / \mathrm{v})$ as a mobile phase, UV-light and $15-20 \% \mathrm{v} / \mathrm{v}$ ethanol/sulfuric spray reagent for spots location, then similar fractions were collected to obtain three main fractions. The second collective fraction was subjected to successive normal silica G column chromatography using the different solvent systems; ethyl acetate: methanol $7: 3 \mathrm{v} / \mathrm{v}$ and methylene chloride: methanol 8:2 v/v to give OA and CA.

\subsection{In vitro cytotoxic activity}

The tested compounds were evaluated for their cytotoxic activity via using SRB assay against three human tumor cell lines; the liver cancer cell line (HepG-2), the colon cancer cell line (HCT-116), and the breast cancer cell line (MCF-7) according to standard reported procedure ${ }^{9}$.

\subsection{Cell cycle analysis and apoptosis}

On HepG-2 cancer cell, cell cycle arrest and apoptosis which was performed by Annexin V-FITC and propidium iodide (PI) double staining assay ${ }^{10}$ then analyzed by the flow cytometer. ${ }^{11}$

\section{RESULTS AND DISCUSSION}

3.1. Identification of the isolated compounds
OA \& CA were off-white amorphous powder, gave pink color on TLC $\left(15 \%\right.$ ethanol $/ \mathrm{H}_{2} \mathrm{SO}_{4}$ at $120^{\circ} \mathrm{C}$ ), positive Liebermann-Burchard, and anisaldehyde test, and negative Molish's test. Negative-ESI-mass; showed [M-H] ${ }^{-}$at m/z 455 and $\mathrm{m} / \mathrm{z} 485$ in agreement with molecular formula $\mathrm{C}_{30} \mathrm{H}_{48} \mathrm{O}_{3}$ for $\mathrm{OA}$ and the molecular formula $\mathrm{C}_{30} \mathrm{H}_{46} \mathrm{O}_{5}$ for CA respectively. ${ }^{1} \mathrm{H}$ NMR $(400 \mathrm{MHz}$, DMSO- $\mathrm{d}_{6}$ ) and ${ }^{13} \mathrm{C}$ NMR (100MHz, DMSO-d 6 ) were illustrated in (table 1).

Oleanolic acid (OA); sapogenin OA Showed in negative ESI- Mass spectrum, the molecular ion peak at $\mathrm{m} / \mathrm{z} 455$ in agreement with the molecular formula $\mathrm{C}_{30} \mathrm{H}_{48} \mathrm{O}_{3}$. The base peak appeared at $\mathrm{m} / \mathrm{z}$ 248 , characteristic for pentacyclic triterpene of $\beta-$ amyrin series with a 12-13 double bonds.

Table (1) The ${ }^{1} \mathrm{H}\left(400 \mathrm{MHz}\right.$, DMSO- $\left.\mathrm{d}_{6}\right)$, and ${ }^{13} \mathrm{C}$ NMR $\left(100 \mathrm{MHz}, \mathrm{DMSO}-\mathrm{d}_{6}\right)$ chemical shifts $\delta / \mathrm{ppm}$ of oleanolic acid and cincholic acid.

\begin{tabular}{|c|c|c|c|c|}
\hline Position & $\mathrm{OA}$ & & & $\mathrm{CA}$ \\
\hline & $\delta_{13 \mathrm{C}}$ & $\delta^{1}{ }_{H}$ & $\delta_{13 \mathrm{C}}$ & $\delta_{1 H}$ \\
\hline 1 & 38.8 & & 39.3 & \\
\hline 2 & 27.4 & & 27.3 & \\
\hline 3 & 77.3 & 3.00 (brd) & 77.3 & 3.01(brd) \\
\hline 4 & 39.4 & & 40.2 & \\
\hline 5 & 55.3 & & 55.2 & \\
\hline 6 & 18.5 & & 18.4 & \\
\hline 7 & 33.3 & & 37.0 & \\
\hline 8 & 39.9 & & 41.2 & \\
\hline 9 & 47.6 & & 47.5 & \\
\hline 10 & 37.1 & & 38.8 & \\
\hline 11 & 23.8 & & 23.8 & \\
\hline 12 & 121.9 & 5.17 (brs) & 121.9 & 5.16 (brs) \\
\hline 13 & 144.3 & & 144.2 & \\
\hline 14 & 41.3 & & 55.8 & \\
\hline 15 & 27.7 & & 27.6 & \\
\hline 16 & 23.4 & & 27.3 & \\
\hline 17 & 46.2 & & 47.0 & \\
\hline 18 & 41.8 & & 45.9 & \\
\hline 19 & 45.9 & & 46.0 & \\
\hline 20 & 30.9 & & 30.8 & \\
\hline 21 & 33.3 & & 33.7 & \\
\hline 22 & 32.9 & & 32.5 & \\
\hline 23 & 28.7 & $\alpha 1.10$ (s) & 28.6 & $\alpha 1.10(s)$ \\
\hline 24 & 15.6 & B0.90 (s) & 15.5 & В 0.93 (s) \\
\hline 25 & 16.5 & B 0.65 (s) & 16.4 & В 0.68 (s) \\
\hline 26 & 17.3 & B0.88 (s) & 17.2 & В 0.88 (s) \\
\hline 27 & 26.1 & $\alpha 1.25(\mathrm{~s})$ & 177.6 & - \\
\hline 28 & 179.1 & - & 179.0 & - \\
\hline 29 & 33.3 & $\alpha 0.73(s)$ & 33.7 & $\alpha 0.72$ (s) \\
\hline 30 & 23.8 & B0.90(s) & 26.0 & В 0.90 (s) \\
\hline
\end{tabular}

s: singlet, brs: broad singlet and brd: broad doublet

The resonances due to seven $\mathrm{sp} 3$ methyl carbons at $\delta$ $28.7,15.6,16.5,17.3,26.1,33.3,23.8$, assigned for C 23, 24, 25, 26, 27, 29, 30 respectively. Two sp2 carbons at $\delta 121.9$ and 144.3 in the ${ }^{13} \mathrm{C}$ NMR 
spectrum of OA, coupled with the corresponding information from the ${ }^{1} \mathrm{H}$ NMR spectrum seven, $3 \mathrm{H}$ each of seven methyls at $1.10(\alpha, S), 0.90(\beta, S)$, $0.69(\beta, S), 0.88(\beta, S), 1.25(\alpha, S), 0.73(\alpha, S)$ and $0.90(\beta, S)$, assigned for $\mathrm{H} 23,24,25,26,27,29$ and 30 respectively and a broad singlet at $\delta 5.17$ of $\mathrm{H}-12$ confirmed the aglycone moiety as 3-hydroxyolean-12-en-28-oic acid. C-3 at $\delta 77.32$ and C-28 at $\delta 179.07$ were characteristic of aglycone with 3 ß -hydroxyl, where $\mathrm{H}-3$ was observed as a broad singlet at $\delta 3.00$. The assignment of all other ${ }^{13} \mathrm{C}$ resonances was proved by their comparison with reported data in the literature ${ }^{12}$. Hence, it was identified as 3 B- hydroxyl- Olean - 12 - en - 28 - oic acid (Figure 1).

Cincholic acid (CA); negative ESI Mass spectrum showed the molecular ion peak [M-H] $]^{-}$at $\mathrm{m} / \mathrm{z} 486$ in agreement with the molecular formula $\mathrm{C}_{30} \mathrm{H}_{46} \mathrm{O}_{5} .{ }^{1} \mathrm{H}-\mathrm{NMR}$ showed a characteristic brs, $1 \mathrm{H}$ resonance at $\delta 5.16$ assigned for $\mathrm{H}-12$ olefinic proton and six singlets, $3 \mathrm{H}$ each of six methyls at $1.10(\alpha, \mathrm{S})$ and $0.90(\beta, S), 0.68(\beta, S), 0.88(\beta, S), 0.72(\alpha, S)$, $0.90(\beta, S)$ assigned for $\mathrm{H}-23,24,25,26,29$ and 30 respectively. ${ }^{13} \mathrm{C}$-NMR showed, carbon resonances due to six sp3 methyl carbons resonances at 28.6, $15.5,16.4,17.2, \quad 33.7 \& 26.0$ assigned for $\mathrm{C} 23,24,25,26,29 \& 30$ respectively, at $\delta 121.9$ and 144.2 of two $\mathrm{sp}^{2}$ olefinic carbons assigned for C-12 and 13 respectively, at $\delta 77.3$ assignable for hydroxylated $\mathrm{C} 3$ and finely two carbon resonance at 177.6 and 179.0 characteristic for two carboxylic groups assigned for $\mathrm{C}-27$ and 28 respectively and confirmed by the downfield shift of $\mathrm{C} 14$ and 17 at $\delta$ 55.8 \& 47.0 respectively. In comparison with reported previous data of $3 \mathrm{~B}-\mathrm{OH} \beta$-amyrin ${ }^{13}$. All the previous data compared with cincholic acid ${ }^{14}$, Therefore CA was identified as 3-ß-hydroxyolean 12-en-27, 28 dioic acid (Figure 1).
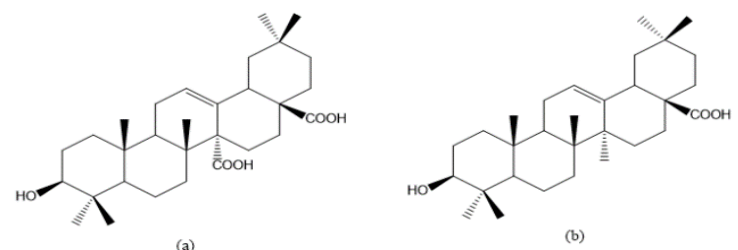

Figure (1): Chemical structure of cincholic $\operatorname{acid}^{15}$ (a) and oleanolic acid ${ }^{16}(b)$.

\subsection{Biology}

\subsubsection{In vitro cytotoxicity}

Cytotoxicity evaluations of both (OA \& $\mathrm{CA}$ ) were performed against three cell lines, MCF-7, HepG-2, and HCT-116 (Table 2). These findings were expressed as values of IC50 and described in
(Table 2). The given information indicated that most of the tested compounds had cytotoxic activity against the three cell lines. However, OA was more cytotoxic than CA against MCF-7 \& HCT-116, while $\mathrm{CA}$ was more cytotoxic than $\mathrm{OA}$ against HEPG-2.

\subsubsection{Cell cycle analysis}

On HepG-2cancer cells, cell cycle arrest was performed. The results obtained showed a significant increase in the number of cells within the G2-M phase and a decrease in the number of cells within the G0-G1 and S phase, whereas the number of cells within the Pre-G1 phase increase as shown in (Table 3 and Figure 2). The findings of the Pre-G1 and G2-M phases revealed that $\mathbf{O A}$ and $\mathbf{C A}$ components induced apoptosis and arrested the cell cycle.

Table (2): In-vitro cytotoxic activity of phytoconstituents oleanolic acid $(\boldsymbol{O A})$ and cincholic acid $(\boldsymbol{C A})$ on the tested human cell lines HEPG-2, MCF-7 and HCT-116.

\begin{tabular}{llll}
\hline & \multicolumn{3}{c}{ IC50 } \\
& $\mu \mathrm{M} / \mathrm{mL}$ & \\
\hline Compounds & HEPG-2 & MCF-7 & HCT-116 \\
\hline$O A$ & $34.21 \pm 1.75$ & $27.99 \pm 1.58$ & $18.66 \pm 0.89$ \\
\hline$C A$ & $22.81 \pm 1.05$ & $30.34 \pm 1.83$ & $25.67 \pm 1.25$ \\
\hline
\end{tabular}

Table (3): Effect of cincholic acid ( $\boldsymbol{C A}$ ) and oleanolic acid $(\boldsymbol{O A})$ on cell cycle of HepG-2 cell line.

\begin{tabular}{llllll}
\hline & \%G0-G1 & $\%$ S & $\begin{array}{l}\% \\
\text { G2-M }\end{array}$ & $\begin{array}{l}\% \\
\text { Pre-G1 }\end{array}$ & \multicolumn{2}{l}{ Comment } \\
\hline CA/ & 42.27 & 20.19 & 37.54 & 16.53 & Cell growth \\
HepG-2 & & & & & arrest $@$ G2/M \\
\hline $\begin{array}{l}\text { OA/ } \\
\text { HepG-2 }\end{array}$ & 45.36 & 21.68 & 32.96 & 13.77 & Cell growth \\
\hline $\begin{array}{l}\text { Cont. } \\
\text { HepG-2 }\end{array}$ & 55.17 & 29.41 & 15.42 & 1.94 & \\
\hline
\end{tabular}

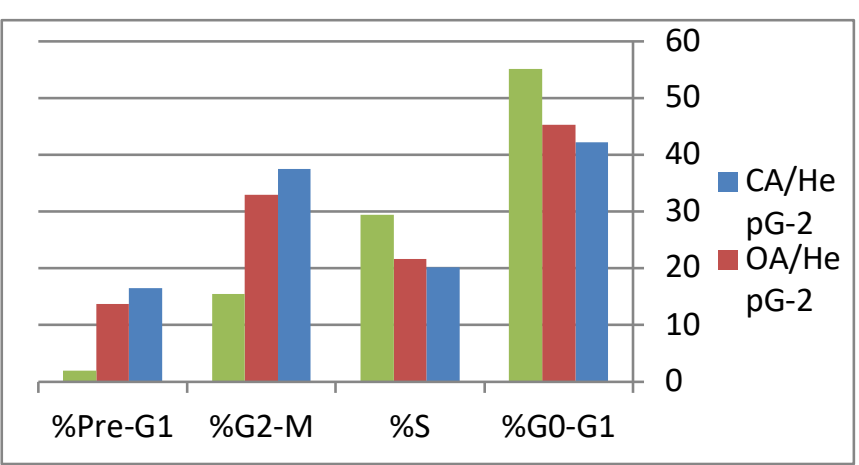

Figure (2): Cell cycle analysis and apoptosis effect of cincholic acid and oleanolic acid on HepG-2. 


\subsubsection{Annexin V-FITC}

The tested components $\mathbf{C A}$ and $\mathbf{O A}$ were evaluated against HepG-2 cells for their apoptotic effect (Table 4 and Figure 3). The findings showed an increase in the ratio of early apoptosis from $0.16 \%$ to $4.65 \%$ and 6.64 , and an increase in the ratio of late apoptosis from $0.27 \%$ to $6.52 \%$ and 7.64, respectively. Such data indicated that the tested components had been positive apoptotic effects.

Table (4): Effect of compounds cincholic acid $(\boldsymbol{C A})$ and oleanolic acid $(\boldsymbol{O} \boldsymbol{A})$ on the percentage of annexin VFITCpositive staining in HepG-2 cells.

\begin{tabular}{lllll}
\hline & \multicolumn{3}{c}{ APOPTOSIS } & \multirow{2}{*}{ NECROSIS } \\
\cline { 1 - 4 } & Total & Early & Late & \\
\cline { 1 - 4 }$C A /$ HEPG-2 & 16.53 & 6.64 & 7.64 & 2.25 \\
\hline OA/ HEPG-2 & 13.77 & 4.65 & 6.52 & 2.6 \\
\hline HEPG-2 & 1.94 & 0.16 & 0.27 & 1.51 \\
\hline
\end{tabular}

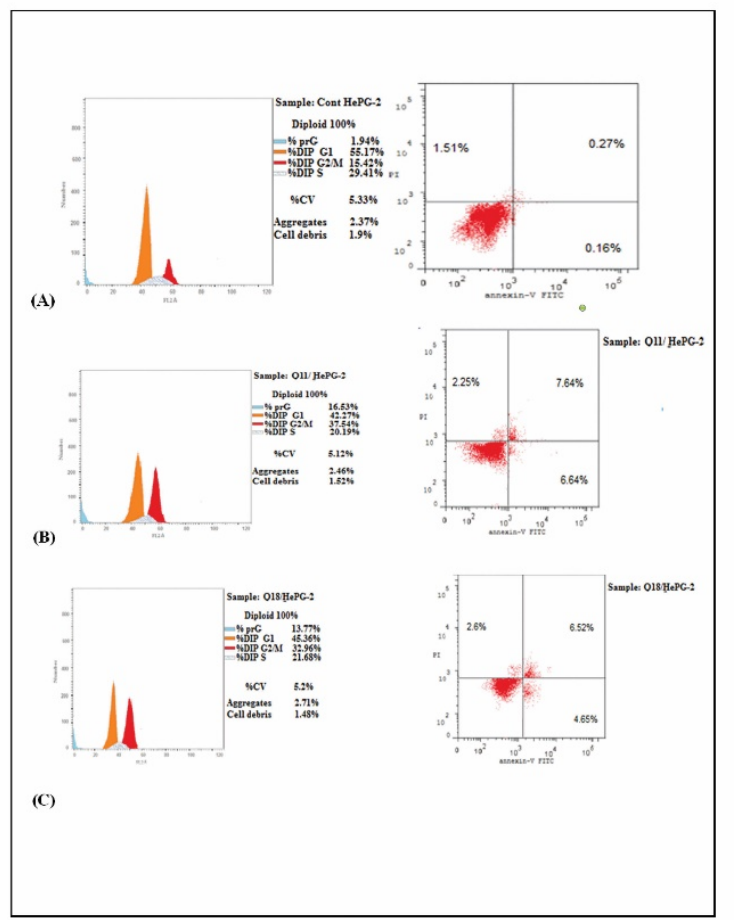

Figure (3): Cell cycle analysis (A) control HEPG-2, (B) cincholic acid, and (C) oleanolic acid by flow cytometry using PI staining.

\section{CONCLUSION}

In this survey we concluded; OA \& $\mathrm{CA}$ as a natural apoptotic agent isolated for the first time from the herb of Lotus glaber mill by chromatographic technique. Against the three tested cell lines, they exhibit anticancer activity. We found that they induce cell cycle arrest at the G2/M period when examined for their effect on the cell cycle HepG-2, the current plant considered as a source of OA \& CA, and recommend for a further clinical trial to be used as phytotherapy for a patient suffering from cancer.

\section{Acknowledgements}

We would like to thank the Faculty of Pharmacy (Girls), Al-Azhar University for providing the laboratory facilities without which the work could not be accomplished and Prof. Dr. Abdel-Halim Abdel-Motjale, Chief Researches and Head of Flora \& Phytotaxonomy Researches Department, Agriculture Museum, for his great efforts in collection and identification of the herb.

\section{Conflict of interest}

The authors declare no conflict of interest.

\section{Ethics statement: NA}

\section{Author contribution}

AS performed the extraction, participated in chromatographic separation of isolated compounds and wrote the paper. MAM revised the paper and conceived the study. ABM shared in the biological study. HSM participated in the structural elucidation of isolated compounds, wrote, and revised the paper and conceived the project.

Funding: This work received no fund

\section{REFERENCES}

1. Liu J. Oleanolic acid and ursolic acid: research perspectives. J Ethnopharmacol.2005; 100:92- 4.

2. Laszczyk MN. Pentacyclic triterpenes of the lupane, oleanane and ursane group as tools in cancer therapy. Planta Med.2009; 75:1549-60.

3. Meng YQ, Liu D, Cai LL, Chen H, Cao B, Wang YZ. The synthesis of ursolic acid derivatives with cytotoxic activity and the investigation of their preliminary mechanism of action. Bioorg Med Chem.2009; 17:848-54.

4. Ma CM, Cai SQ, Cui JR, Wang RQ, Tu PF, Hattori $\mathrm{M}$, et al. The cytotoxic activity of ursolic acid derivatives. Eur J Med Chem. 2005; 40:582-9. 5. Basu N, Rastogi RP. Triterpenoid saponins and sapogenins. Phytochemistry.1967; 6:1249-1270.

6. Fai, Y.M.; Tao, C.C. A review of the presence of oleanolic acid in natural products. Nat. Prod.2009; 277-290. 
7. Zhao, H.; Zhou, M.; Duan, L.; Wang, W.; Zhang, J.; Wang, D.; Liang, X. Efficient synthesis and antifungal activity of oleanolic acid oxime esters, Molecules.2013; 18, 3615-3629.

8. Li W, Zhou J, Xu Y. Study of the in vitro cytotoxicity testing of medical devices (review). Biomedical Reports. 2015; 3:617-620.

9. Skehan P, Storeng R, Scudiero D, Monks A, McMahon J, Vistica D, Warren JT, Bokesch H, Kenney $\mathrm{S}$ and Boyd MR. New colorimetric cytotoxicity assay for anticancer-drug screening. J Natl Cancer Inst.1990; 82(13):1107-1112.

10. Vermes I., C. Haanen, H. Steffens-Nakken, C. Reutellingsperger, A novel assay for apoptosis flow cytometric detection of phosphatidylserine expression on early apoptotic cells using fluorescein-labeled annexin V, J. Immunol. Methods.1995; 184 (1) 39-51.

11. Dressler LG, Bartow MA, Bartow SA.DNA flow cytometry in solid tumors: practical aspects and clinical applications. Semin Diagnostic Pathol.1989; 6:55-82.

12. Gohari AR, Saeidnia S, Hadjiakhoondi A, Abdullahi $M$, and Nezafati $M$. Isolation and quantitative analysis of oleanolic acid from Satureja mutica Fisch, and C.A. Mey. J. Med.Plants.2009; 8: 65-69.

13. Rumbero- Sanchez, A. and Vazquez, P., Quinic acid esters from Isertia haenkeana, Phytochemistry.1991; 30,623.

14. Knight, S. A., Carbon-13 NMR spectra of some tetra, and pentacyclic triterpenoids, org.Magn.Reson.1974; 6,603.

15. Daiane, M., and Cecilia, V. N. Secondary Metabolites from Rubiaceae species. Molecules.2015; 20, 13422-13495.

16. Wang, Y.Y., Yang, Y.X., Zhe, H., He, Z.X., Zhou, S.F. Bardoxolone methyl (CDDO-Me) as a therapeutic agent: an update on its pharmacokinetic and pharmacodynamic properties. Drug Des. Dev. Ther. 2014; 8, 2075-2088. 